\title{
Hepatologie - úvod do problematiky
}

Vážení čtenáři časopisu Vnitřní lékařství,

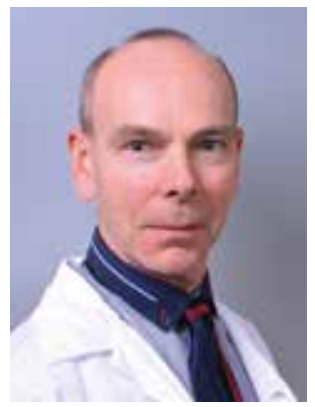

v aktuálním čísle vám předkládáme první část „,kapesní hepatologie" - stručného přehledu aktuálních témat současné hepatologie. Původní ucelený soubor textů byl redakcí rozdělen na dvě části, a tak druhá část přehledu bude součástí některého $z$ příštích čísel Vnitřního lékařství. Hepatologie je obor, ve kterém došlo $v$ průběhu posledních desetiletí k rychlému vývoji a který dnes nabízí stále většímu počtu nemocným kompletní vyléčení jejich choroby či významné prodloužení a zlepšení kvality života. V důsledku rozvoje neinvazivních diagnostických metod se kompletně změnila diagnostika jaterních chorob. V posledních letech se kompletně změnila i léčba některých chorob - dnes např́klad umíme vyléčit téměř všechny pacienty $s$ chronickou hepatitidou C. Zcela rutinní metodou se stala transplantace jater a Česká republika patř́ jak počtem transplantací na počet obyvatel, tak i krátkou dobou na čekací listině mezi přední státy v Evropě. Př́íladem dalšího úspěchu je péče o pacienty $s$ krvácením $z$ varixů - v průběhu 3 desetiletí se podařilo snížit mortalitu na tuto komplikaci cirhózy ze $45 \%$ na 10-15\%.

Nehledě na tyto úspěchy a pokrok se $s$ pacienty s jaterními chorobami setkáváme a budeme setkávat i nadále. Ukazuje se, že jaterní choroby představují významnou zdravotní zátěž současné populace. Předpokládá se, že v současnosti jen v Evropě trpí asi 30 milionů jedinců některou z chronických jaterních chorob [1]. Většina chronických jaterních chorob souvisí s nadměrným príimem alkoholu, nealkoholovou jaterní steatózou - NAFLD (v souvislosti s nadváhou, diabetem a metabolickým syndromem), nebo virovými hepatitidami B a C. Pomyslnou špičkou ledovce ve vývoji jaterních chorob je jaterní cirhóza - většina úmrtí, která se vztahují k jaterním chorobám, je dána právě přítomností jaterní cirhózy a jejích komplikací. Z tohoto pohledu zemře v ČR více obyvatel na jaterní choroby než napří-

Schéma 1. Základni hodnoceni jaterni léze dle hodnot ALT a ALP

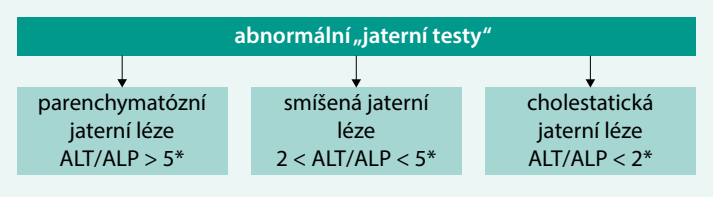

*Poměr ALT/ALP je hodnocen jako poměr násobků normy pro dané vyšetření klad na chronickou plicní nemoc nebo karcinom prsu. Dnes je také jasně prokázáno, že přítomnost nejčastější chronické jaterní choroby - NAFLD znamená zvýšené kardiovaskulární riziko i zvýšené riziko onkologických onemocnění pro daného jedince, ale představuje i významnou ekonomickou zátěž pro zdravotnický systém [2]. Péče o pacienty s NAFLD navíc vyžaduje těsnou spolupráci mezi lékaři všech odborností, kteří se podílejí na péči o pacienty s jednotlivými komponentami metabolického syndromu.

\section{Hodnocení jaterního postižení a klinická manifestace jaternich chorob}

Parametrem jaterního poškození je v běžné praxi zvýšení hodnot tzv. jaterních testů. V užším slova smyslu se takto označují parametry ukazující na jaterní poškození (ALT, AST, ALP, GGT), v širším pohledu pak i jednoduché parametry jaterních funkcí (bilirubin, albumin, INR). ALT se nachází v cytoplaymě hepatocytů, AST pak v cytoplazmě i mitochondriích. Ani jeden z enzymů není specifický čistě pro játra, nicméně oba se v játrech nacházejí ve vysokých koncentracích a jejich zvýšení v séru je průvodním jevem hepatocelulárního poškození. Izolované zvýšení AST by však mělo vést k podezření na mimojaterní původ enzymu.

Podobně jako u mnoha laboratorních hodnot, normální hodnoty AST a ALT byly získány vyšetřením určitého počtu „zdravých" osob. Mnoho těchto jedinců však mohlo mít nepoznanou nealkoholovou jaterní steatózu nebo $v$ dřívější době nevyšetřovanou hepatitidu $C$ a je otázkou, zda naše současné limity jsou skutečně "normální". Je např́klad známo, že jedinci s hodnotami ALT a AST bližícími se k horní hranici normy mají vyšší mortalitu na jaterní choroby než jedinci s hodnotami transamináz na dolní hranici normy [3]. Dalším méně známým faktem je skutečnost, že velké procento pacientů se steatózou, pokročilou fibrózou, či dokonce cirhózou má „jaterní testy" trvale v mezích normy. Dalším nezbytným vyšetřením ve screeningu jaterních chorob je tedy ultrasonografie, která odhalí biochemicky "němou“ jaterní steatózu.

Parametrem cholestázy je enzym alkalická fosfatáza (ALP), není to však enzym specifický pro játra či biliární strom, nachází se i ve střevě, ledvinách, kostech a placentě. Gamaglutamyl transferáza (GGT) je mikrosomální enzym, velmi citlivý i k minimálnímu jaternímu poškození. Izolovaná elevace GGT není cholestázou, bývá př́tomna u alkoholového poškození, NAFLD nebo při polékovém poškození. Při současné elevaci ALP odpovídá cholestáze.

Klinické projevy jaterních chorob se mohou pohybovat od zcela bezpríznakových stavů, pres nespecifické symptomy, jako je únava, nauzea, nechutenství, 
pruritus, až k projevům pokročilé jaterní choroby, jako je ascites, ikterus, pavoučkové névy apod.

Zásadní rozvahou u pacienta s elevací jaterních enzymů je rozhodnutí, zda se jedná o parenchymatózní (hepatocelulární) poškození nebo cholestatickou jaterní lézi. K parenchymatózní lézi patří elevace ALT a AST, pro cholestázu je typická elevace ALP (schéma 1). 10násobné zvýšení hodnot AST a ALT většinou odpovídá probíhající nekróze hepatocytů. Nižší hodnoty ALT již tak dobře s histologickým obrazem nekrózy nekorelují. Výrazně vysoké hodnoty ALT (> 10násobek normy) jsou typické pro virové hepatitidy, polékové či toxické postižení, ischemii, akutní manifestaci autoimunní hepatitidy nebo přechodnou akutní biliární obstrukci při průchodu konkrementu. Poměr AST/ALT je důležitý k posouzení etiologie jaterní léze - hodnoty AST vyšší než ALT jsou typické a téměř specifické pro alkoholové poškození. U čisté cholestázy je vždy nezbytné vyloučit mechanickou biliární obstrukci; až poté můžeme mluvit o intrahepatální cholestáze. Smíšená léze je nejčastěji způsobena polékovým poškozením (v literatuře se nyní uvádí jako DILI - Drug Induced Liver Injury). Jednoduchý základní postup v diferenciální diagnostice jaterní léze uvádí schéma 2 a schéma 3.

\section{Schéma 2. Přistup k pacientovi s parenchymatózni jaterni lézí. Upraveno podle [4]}

\begin{tabular}{|c|c|}
\hline \multicolumn{2}{|c|}{$\begin{array}{l}\text { parenchymatózní jaterní léze } \\
\text { ALT/ALP > } 5\end{array}$} \\
\hline & $\begin{array}{l}\text { anamnéza, fyzikální vyšetření } \\
\text { rizikové faktory virových hepatitid } \\
\text { medikace (včetně prírodních preparátů!) } \\
\text { alkohol } \\
\text { metabolický syndrom, obezita, diabetes }\end{array}$ \\
\hline $\begin{array}{l}\quad \text { ALT > 10násobek normy } \\
\text { - sérologie virových hepatitid (A, B, C, E) } \\
\text { - ANA, ASMA (autoimunitní hepatitida) } \\
\text { - ultrasonografie (vyloučení Buddova- } \\
\text { - Chiariho syndromu) } \\
\text { - toxikologické vyšetření } \\
\text { - sérologie EBV }\end{array}$ & $\begin{array}{l}\quad \text { ALT < 10násobek normy } \\
\text { - sérologie virových hepatitid (A, B, C, E) } \\
\text { - ANA, ASMA (autoimunitní hepatitida) } \\
\text { - ceruloplazmin (Wilsonova choroba) } \\
\text { - feritin (hemochromatóza) } \\
\text { - NAFLD/NASH } \\
\text { - celiakie }\end{array}$ \\
\hline
\end{tabular}

\section{Schéma 3. Přistup k pacientovi s cholestatickou jaterni lézi. Upraveno podle [4]}

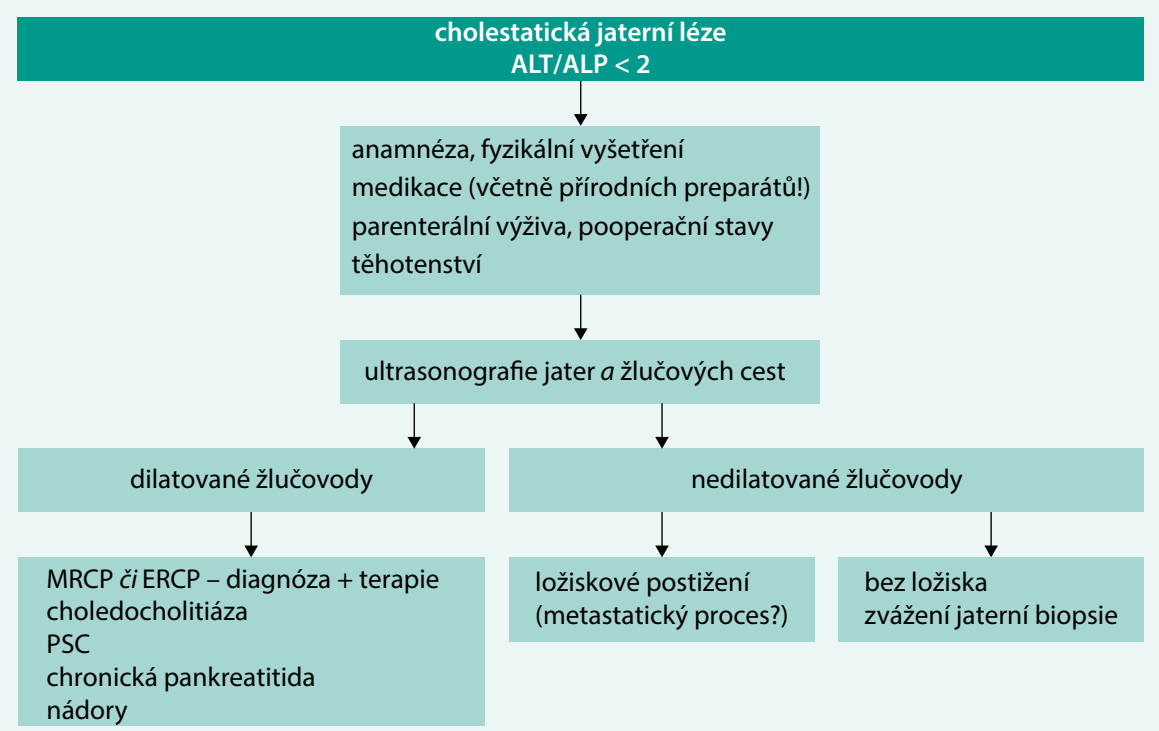


Dalším zásadním rozhodnutím je určení, zda se jedná o akutní (a přechodné) zvýšení jaterních testů, či zda se jedná o chronické onemocnění. Přechodné (lehké) zvýšení jaterních testů může mít po různých inzultech v průběhu života téměř každý jedinec, naproti tomu chronická jaterní choroba znamená trvalou a dlouhodobou prítomnost vyvolávajícího faktoru, a tím riziko tvorby a ukládání vaziva (fibrotizace). Akutní jaterní léze se u naprosté většiny pacientů upraví do plné normy, chronická jaterní léze může vést k jaterní cirhóze.

Z pohledu chronických jaterních chorob je pokročilost jaterní fibrózy jednou z nejpodstatnějších informací týkající se prognózy. Dříve byly naše možnosti $v$ hodnocení pokročilosti fibrózy velmi omezené pro nutnost jaterní biopsie; v poslední době se uplatňují neinvazivní postupy, které jaterní biopsii v této indikci téměř kompletně nahradily. Stejně tak byly velmi omezené léčebné možnosti; $v$ dnešní době díky moderní léčbě i poznatkům o fibrogenezi můžeme u podstatné části pacientů uvažovat o regresi fibrózy (a do určité míry i cirhózy). Problematika jaterní fibrózy - možnosti její detekce a terapeutického ovlivnění u pacientů s chronickými jaterními chorobami jsou jedním z hlavních témat a výzev současné hepatologie, které jsme se snažili zohlednit ve výběru a zpracování článků do hepatologického čísla Vnitřního lékařství.
Vážení a milí čtenáři, za autorský kolektiv vám přeje příjemné chvíle strávené při čtení aktuálního čísla Vnitřní lékařsví

\section{Radan Brůha}

\section{Literatura}

1. Blachier M, Leleu H, Peck-Radosavljevic M et al. The burden of liver Blachier M, Leleu H, Peck-Radosavljevic M et al. The burden of liver disease in Europe: a review of available epidemiological data. J Hepatol 2013; 58(3): 593-608. Dostupné z DOI: <http://dx.doi.org/10.1016/j. jhep.2012.12.005>.

2. Baumeister SE, Volzke $H$, Marschall $P$ et al. Impact of fatty liver disease on health care utilization and costs in a general population: a 5 -year observation. Gastroenterology 2008; 134(1): 85-94. Dostupné z DOI: <http://dx.doi.org/10.1053/j.gastro.2007.10.024>.

3. Kim HC, Nam CM, Jee $\mathrm{SH}$ et al. Normal serum aminotransferase concentration and risk of mortality from liver diseases: prospective cohort study. BMJ 2004; 328(7446): 983. Dostupné z DOI: <http:// dx.doi.org/10.1136/bmj.38050.593634.63>.

4. Weinstein WM, Hawkey C, Bosch J. Clinical Gastroenterology and Hepatology. Elsevier - Mosby: Philadelphia, USA 2005. ISBN-10: 0323035965. ISBN-13: 978-0323035965.

prof. MUDr. Radan Brůha, CSc. $\triangle$ bruha@cesnet.cz

spolueditor tohoto čísla časopisu Vnitřní lékařství

IV. interní klinika 1. LF UK a VFN v Praze

www.int4.If1.cuni.cz

Doručeno do redakce 14. 4. 2019 